\title{
MicroRNAs as Modulators of the Immune Response in T-Cell Acute Lymphoblastic Leukemia
}

\author{
Martina Del Gaizo ${ }^{1,+}$, Ilaria Sergio ${ }^{2,+}$, Sara Lazzari ${ }^{1}$, Samantha Cialfi ${ }^{1}$, Maria Pelullo ${ }^{3}$, Isabella Screpanti ${ }^{1, *}$ and \\ Maria Pia Felli $2, *$ (D)
}

check for

updates

Citation: Del Gaizo, M.; Sergio, I.;

Lazzari, S.; Cialfi, S.; Pelullo, M.;

Screpanti, I.; Felli, M.P. MicroRNAs as Modulators of the Immune

Response in T-Cell Acute

Lymphoblastic Leukemia. Int. J. Mol.

Sci. 2022, 23, 829. https://doi.org/

$10.3390 /$ ijms 23020829

Academic Editor: Haifa

Kathrin Al-Ali

Received: 3 December 2021

Accepted: 10 January 2022

Published: 13 January 2022

Publisher's Note: MDPI stays neutral with regard to jurisdictional claims in published maps and institutional affiliations.

Copyright: (C) 2022 by the authors. Licensee MDPI, Basel, Switzerland. This article is an open access article distributed under the terms and conditions of the Creative Commons Attribution (CC BY) license (https:// creativecommons.org/licenses/by/ $4.0 /)$.
1 Department of Molecular Medicine, Sapienza University of Rome, 00161 Roma, Italy; delgaizo.1844853@studenti.uniroma1.it (M.D.G.); sara.lazzari@uniroma1.it (S.L.);

Samantha.cialfi@uniroma1.it (S.C.)

2 Department of Experimental Medicine, Sapienza University of Rome, 00161 Roma, Italy; Ilaria.sergio@uniroma1.it

3 Center for Life Nano Science@Sapienza, Istituto Italiano di Tecnologia, 00161 Rome, Italy; maria.pelullo@uniroma1.it

* Correspondence: Isabella.screpanti@uniroma1.it (I.S.); mariapia.felli@uniroma1.it (M.P.F.)

$\dagger$ These authors contributed equally to this work.

\begin{abstract}
Acute lymphoblastic leukaemia (ALL) is an aggressive haematological tumour driven by the malignant transformation and expansion of B-cell (B-ALL) or T-cell (T-ALL) progenitors. The evolution of T-ALL pathogenesis encompasses different master developmental pathways, including the main role played by Notch in cell fate choices during tissue differentiation. Recently, a growing body of evidence has highlighted epigenetic changes, particularly the altered expression of microRNAs (miRNAs), as a critical molecular mechanism to sustain T-ALL. The immune response is emerging as key factor in the complex multistep process of cancer but the role of miRNAs in anti-leukaemia response remains elusive. In this review we analyse the available literature on miRNAs as tuners of the immune response in T-ALL, focusing on their role in Natural Killer, T, T-regulatory and Myeloidderived suppressor cells. A better understanding of this molecular crosstalk may provide the basis for the development of potential immunotherapeutic strategies in the leukemia field.
\end{abstract}

Keywords: microRNA; Notch; Natural Killer cells; T and regulatory T cells; MDSC; Acute lymphoblastic leukaemia

\section{Introduction}

Over the last 30 years, microRNAs (miRNAs) have been the subject of much interest in molecular biology, both for clinical diagnostics and as therapeutic targets in human diseases.

The role that the immune system plays in cancer is now well established, as is the fact that miRNAs act as downstream and upstream modulators that activate important factors such as nuclear factor kappa-B (NF-kB), signal transducers and activators of transcription 3 (STAT3), tumour necrosis factor (TNF), and transforming growth factor $\beta$ (TGF $\beta$ ), which tune many immune cell functions [1]. However, the mechanism that regulates the expression of these miRNAs is still unclear.

To date, some 2000 miRNAs are known to be involved in the regulation of $30-40 \%$ of the genes in the human genome that regulate all aspects of cell proliferation, differentiation and function [2]. Abnormal gene expression by miRNAs is associated with the progression of cancer, inflammatory diseases or autoimmune diseases. This has shed new light on the mechanisms of interaction between cancer and inflammation [3].

Epidemiological studies suggest that as many as $25 \%$ of all cancers may be due to an extrinsic pathway driven by inflammatory conditions and an intrinsic pathway driven by oncogenic alterations that create an inflammatory microenvironment [4]. 
Immune cells produce various growth factors such as chemokines and cytokines or proteinases that can all create a pro-inflammatory tumour microenvironment. Intercellular communication between cancer and immune cells plays a key role in modulating the immune response, thereby promoting cell migration and proliferation, and tumour progression [5].

The aim of this review is to analyse in depth the miRNAs in the context of Natural Killer (NK), T, T-regulatory (Treg) and myeloid derived suppressor cells (MDSCs) (Table 1), all involved in the crosstalk between the immune microenvironment and cancer cells in haematological malignancies, in particular T-ALL.

Table 1. miRNAs involved in ALL immune response.

\begin{tabular}{|c|c|c|c|c|c|c|}
\hline & T Cells & NK & T Reg & MDSC & T-ALL & Reference \\
\hline miR-15-16 & - & $\begin{array}{l}\text { Promotes the } \\
\text { transition to } \\
\text { stage } 4 \\
\left(\mathrm{CD}^{-} 7^{-} \mathrm{CD} 11 \mathrm{~b}^{+}\right) \\
\text {during NK } \\
\text { maturation }\end{array}$ & - & - & $\begin{array}{c}\text { Blocks NK cell maturation } \\
\text { and leads to accumulation } \\
\text { of immature stage- } 2 \text { and } \\
\text { stage- } 3 \text { cells }\end{array}$ & [6] \\
\hline $\operatorname{miR}-16-2-3 p$ & - & - & $\begin{array}{l}\text { Blocks the } \\
\text { function in the } \\
\text { tumour microen- } \\
\text { vironment by } \\
\text { inhibiting } \\
\text { PD1/PDL1 } \\
\text { signalling } \\
\text { pathway }\end{array}$ & $\begin{array}{l}\text { Blocks the } \\
\text { function in the } \\
\text { tumour microen- } \\
\text { vironment by } \\
\text { inhibiting } \\
\text { PD1/PDL1 } \\
\text { signalling } \\
\text { pathway }\end{array}$ & $\begin{array}{l}\text { Down-regulation in ALL } \\
\text { leads to the recruitment of } \\
\text { both MDSCs and Tregs; } \\
\text { inhibits functional T-cell } \\
\text { responses in ALL }\end{array}$ & {$[7,8]$} \\
\hline Cluster 17-92 & $\begin{array}{c}\text { Increases T-cells } \\
\text { proliferation and } \\
\text { survival in } \\
\text { DN-DP } \\
\text { transition; high } \\
\text { expression leads } \\
\text { to } \\
\text { autoimmunity }\end{array}$ & - & - & - & $\begin{array}{l}\text { Negatively regulates E2F1 to } \\
\text { suppress T-ALL apoptosis }\end{array}$ & [9-11] \\
\hline $\operatorname{miR}-21$ & - & - & $\begin{array}{l}\text { Induces IL-10 and } \\
\text { impairs Treg cell } \\
\text { function }\end{array}$ & - & $\begin{array}{l}\text { Up-regulation in T-ALL } \\
\text { promotes survival } \\
\text { suppressing Pdcd } 4 \text { at least } \\
\text { by stabilization of BCL-XL } \\
\text { protein levels; } \\
\text { immunosuppressive effects } \\
\text { of IL-10 by Tregs leads to } \\
\text { unchecked inflammation } \\
\text { and promotes T-ALL } \\
\text { progression }\end{array}$ & [12-14] \\
\hline $\operatorname{miR}-26$ & - & - & $\begin{array}{l}\text { Promotes Tregs } \\
\text { production and } \\
\text { function by } \\
\text { targeting IL-6 }\end{array}$ & - & $\begin{array}{l}\text { Down-regulation in T-ALL } \\
\text { patients leads to decreased } \\
\text { apoptosis and induction of } \\
\text { proliferation caused by } \\
\text { failed repression of PIK3CD }\end{array}$ & {$[15,16]$} \\
\hline $\mathrm{miR}-29 \mathrm{a} / \mathrm{b}$ & $\begin{array}{c}\text { miR-29a acts as } \\
\text { tumour } \\
\text { suppressor } \\
\text { targeting } \\
\text { DNMT3a and } \\
\text { DNMT3b to } \\
\text { reduce } \\
\text { methylation in } \\
\text { leukemic T-cells }\end{array}$ & $\begin{array}{l}\text { miR-29b represses } \\
\text { NK cells cytotoxic } \\
\text { function and } \\
\text { differentiation in } \\
\text { Notch1-T-ALL }\end{array}$ & - & - & $\begin{array}{c}\text { miR-29b downregulation in } \\
\text { T-ALL causes altered } \\
\text { epigenetic status activating } \\
\text { methylation of DNMT3a, } \\
\text { DNMT3b and TET1; } \\
\text { miR-29b up-regulation via } \\
\text { vesicular release by } \\
\text { leukemic cells influences } \\
\text { NK cell } \\
\text { development; miR-29a low } \\
\text { expression in T-ALL }\end{array}$ & [17-20] \\
\hline
\end{tabular}


Table 1. Cont.

\begin{tabular}{|c|c|c|c|c|c|c|}
\hline & T Cells & NK & T Reg & MDSC & T-ALL & Reference \\
\hline $\operatorname{miR}-34 a-5 p$ & $\begin{array}{c}\text { miR-34a acts as } \\
\text { tumour } \\
\text { suppressor, } \\
\text { central NF-KB } \\
\text { regulator in T-cell }\end{array}$ & - & - & $\begin{array}{l}\text { Up-regulation of } \\
\text { miR- } 34 a-5 p \\
\text { promotes the } \\
\text { expansion of } \\
\text { MDSCs }\end{array}$ & $\begin{array}{l}\text { Down-regulation in T-ALL } \\
\text { impacts the NF- } \mathrm{KB} \\
\text { signalosome increasing } \\
\text { surface abundance of TCRA } \\
\text { and CD3E caused by lost } \\
\text { targeting of NF- } \mathrm{BBIA} \text { and } \\
\text { five PKC isozymes }\end{array}$ & [21-23] \\
\hline $\operatorname{miR}-133 b$ & - & - & $\begin{array}{l}\text { Modulates Tregs } \\
\text { differentiation by } \\
\text { IL-17A expression }\end{array}$ & - & $\begin{array}{l}\text { Reduced expression in } \\
\text { association with low levels } \\
\text { of IL-17 levels in T-ALL }\end{array}$ & {$[16,24]$} \\
\hline miR-142-3p & $\begin{array}{l}\text { Modulated in } \\
\text { thymocytes } \\
\text { differentiation }\end{array}$ & - & - & - & $\begin{array}{l}\text { Over-expression in T-ALL } \\
\text { reduces cAMP levels and } \\
\text { interacts with PKA, to } \\
\text { increase } \\
\text { leukemic T-cell growth; } \\
\text { targeting GRa it induces } \\
\text { glucorticoid resistance }\end{array}$ & [25] \\
\hline miR-146b-5p & $\begin{array}{l}\text { High expression } \\
\text { in thymocytes } \\
\text { regulates the } \\
\text { DP-SP transition }\end{array}$ & - & - & - & $\begin{array}{l}\text { Tumour suppressor function } \\
\text { delaying progression of } \\
\text { T-ALL; Downregulated by } \\
\text { over-expressed TAL1 in } \\
\text { T-ALL patients }\end{array}$ & [26] \\
\hline miR-150 & $\begin{array}{l}\text { Modulates T-cell } \\
\text { differentiation; } \\
\text { regulates Notch3 } \\
\text { expression }\end{array}$ & $\begin{array}{l}\text { Promotes NK cell } \\
\text { survival and } \\
\text { maturation }\end{array}$ & $\begin{array}{l}\text { Up-regulation } \\
\text { blocks mTOR } \\
\text { pathway and } \\
\text { enhances Treg cell } \\
\text { differentiation }\end{array}$ & - & $\begin{array}{l}\text { Induces accumulation of } \\
\text { hyperfunctional mature NK } \\
\text { cells; inversely correlated to } \\
\text { Notch3 expression }\end{array}$ & [27-29] \\
\hline miR-155 & $\begin{array}{l}\text { Positively } \\
\text { regulates Th17 } \\
\text { differentiation. } \\
\text { Pivotal role in } \\
\text { regulation of } \\
\text { T-cell response } \\
\text { during T-cell } \\
\text { activation }\end{array}$ & $\begin{array}{l}\text { Promotes the } \\
\text { transition to stage } \\
\qquad 4 \\
\left(\mathrm{CD}^{-} 7^{-} \mathrm{CD}^{\left.-11 b^{+}\right)}\right. \\
\text {during NK cell } \\
\text { maturation }\end{array}$ & $\begin{array}{l}\text { Targets FOXP3, to } \\
\text { modulating Tregs } \\
\text { differentiation } \\
\text { and function; } \\
\text { affects IL-2 } \\
\text { production by } \\
\text { inhibiting SOCS1 } \\
\text { to regulate Treg } \\
\text { proliferation }\end{array}$ & $\begin{array}{l}\text { Down-regulation } \\
\text { promotes } \\
\text { expansion of } \\
\text { functional } \\
\text { MDSCs by } \\
\text { targeting SHIP-1 } \\
\text { and PTEN }\end{array}$ & $\begin{array}{l}\text { Blocks NK cell maturation } \\
\text { and leads to immature stage } \\
2 \text { and } 3 \text { cells accumulation; } \\
\text { Low-expression, induced by } \\
\text { IL-10, promotes T-ALL } \\
\text { progression }\end{array}$ & {$[12,30-36]$} \\
\hline miR-181 & $\begin{array}{l}\text { High expression } \\
\text { during the DP } \\
\text { stage and low } \\
\text { mature T-cells }\end{array}$ & $\begin{array}{l}\text { Up-regulates } \\
\text { Notch signalling } \\
\text { in NK cell } \\
\text { development by } \\
\text { targeting NLK }\end{array}$ & - & - & $\begin{array}{l}\text { Is a tumour suppressor in } \\
\text { ALL with over-expression of } \\
\text { Smad7 and regulates } \\
\text { TGF } \beta 1 / \text { Smad pathway }\end{array}$ & [37-39] \\
\hline $\operatorname{miR}-210$ & - & - & $\begin{array}{l}\text { Up-regulates } \\
\text { FOXP3 and } \\
\text { arginase 1, and } \\
\text { enhances Treg } \\
\text { cells function }\end{array}$ & $\begin{array}{l}\text { Regulates MDSC } \\
\text { function by } \\
\text { increasing } \\
\text { arginase activity } \\
\text { and nitric oxide } \\
\text { production and, } \\
\text { in splenic MDSC, } \\
\text { regulates arg1, } \\
\text { CXCL12and IL16 }\end{array}$ & $\begin{array}{l}\text { Up-regulation of miR-210 in } \\
\text { ALL patients may } \\
\text { potentiated } \\
\text { immunosuppressive activity } \\
\text { of tumour MDSCs }\end{array}$ & {$[40,41]$} \\
\hline $\operatorname{miR}-223$ & $\begin{array}{l}\text { High expression } \\
\text { in early } \\
\text { thymocytes; } \\
\text { down-regulation } \\
\text { in DN2-DN3 } \\
\text { stage }\end{array}$ & - & - & $\begin{array}{l}\text { Down-regulation } \\
\text { represses the } \\
\text { differentiation } \\
\text { and } \\
\text { accumulation of } \\
\text { MDSCs by } \\
\text { targeting MEF2C }\end{array}$ & $\begin{array}{l}\text { Inhibits the expression of } \\
\text { the tumour suppressor } \\
\text { FBXW7 and induces T-ALL } \\
\text { cell growth in a } \\
\text { Notch-dependent manner }\end{array}$ & [42-45] \\
\hline miR-325 & $\begin{array}{l}\text { Controls T-cell } \\
\text { proliferation and } \\
\text { apoptosis by } \\
\text { binding BAG2 }\end{array}$ & - & - & - & $\begin{array}{l}\text { Low-expression enhances } \\
\text { BAG2 levels in patients with } \\
\text { T-ALL and promotes cancer } \\
\text { cells proliferation }\end{array}$ & [46] \\
\hline
\end{tabular}


Table 1. Cont.

\begin{tabular}{|c|c|c|c|c|c|c|}
\hline & T Cells & NK & T Reg & MDSC & T-ALL & Reference \\
\hline $\operatorname{miR}-483-3 p$ & - & $\begin{array}{l}\text { Involved in the } \\
\text { development and } \\
\text { cytolytic function } \\
\text { of NK by } \\
\text { modulating IGF-1 }\end{array}$ & - & - & $\begin{array}{l}\text { Higher expression level } \\
\text { plays a positive role in } \\
\text { T-ALL pathophysiology }\end{array}$ & {$[47,48]$} \\
\hline miR-653-5p & $\begin{array}{l}\text { Enhances } \\
\text { apoptosis and } \\
\text { autophagy }\end{array}$ & - & - & - & $\begin{array}{l}\text { Negatively regulated by } \\
\text { circ-PRKD promotes T-ALL } \\
\text { cell proliferation }\end{array}$ & [49] \\
\hline
\end{tabular}

This table describes all the miRNAs that have been implicated in the immune response. It describes their expression and function in NK, T and Tregs, and MDSC cells and their deregulation in T-ALL. Keyword: miRNAs, Notch, T cells, Natural Killers (NK), T-regulatory cells (Tregs), Myeloid-derived suppressor cells (MDSCs), Acute Lymphoblastic Leukaemia (ALL), T-cell ALL (T-ALL); PD1: programmed death 1; PDL-1: programmed ligand death 1; DN: double negative; DP: double positive; SP: single positive; E2F1: E2F transcription factor 1; IL-2/IL6/IL-10/IL-16/IL-17: Interleukin 2/6/10/16/17; DNMT3a/b: DNA (cytosine-5)-methyltransferase 3a/b; cAMP. cyclic adenosine monophosphate; PKA: proteinase Kinase A; PTEN: phosphatase and tensin homolog; SHIP1: Src homology 2 (SH2) domain-containing inositol polyphosphate 5'-phosphatase 1; mTOR: mechanistic target of rapamycin; SOCS1: suppressor of cytokine signalling 1; SMAD7: small mother against decapentaplegic; TGF- $\beta$ : transforming growth factor beta; FOXP3: forkhead box P3; CXCL12: C-X-C motif chemokine 12; BAG2: BCL-2associated athanogene; PRKD: protein kinase D; MEF2C: myocyte-specific enhancer factor 2C; IGF1: insulin-like growth factor 1 .

\section{T-Cell Acute Lymphoblastic Leukaemia}

Acute Lymphoblastic Leukaemia (ALL) is a heterogeneous disease that causes malignant haematological disorders at any age. It mainly affects children aged 2 to 5 ; in fact, $60 \%$ of paediatric leukaemia cases are ALL, with an incidence of 3-4 cases per 100,000 per year. It is divided into two subtypes B-ALL and T-ALL depending on whether transformation occurs in B- or T-cell precursors, respectively [50].

The evolutionarily conserved Notch signalling pathway plays a critical role in cell fate choices in many tissues and its dysregulation contributes to the development of various malignancies, including T-ALL. Four Notch paralogues (Notch1-4) in mammals bind transmembrane ligands of the Jagged family (Jagged-1, Jagged-2) or the Delta-like family (DLL1, DLL3 and DLL4) [51]. Through a multistep proteolytic process, the intracellular domain of Notch (NICD) is released and translocated into the nucleus where it complexes with the DNA-binding CSL/RBP-Jk factor, the Mastermind-like co-activator (MAML1-3) and other nuclear factors to form the Notch transcriptional complex that then regulates the transcription of multiple genes [52,53].

Loss-of-function or gain-of-function experiments suggest that Notch blocks B-cell differentiation by inducing lymphoid progenitor cells towards T-lineage differentiation. In the absence of the Notch signalling pathway, progenitor cells enter the thymus and differentiate into the B-cell lineage. In contrast, when the receptor is constitutively expressed there is inhibition of B-lineage differentiation with an accumulation of T-cells [54]. Indeed, constitutive activation of Notch signalling pathway drives to T-ALL, whereas potent activation of Notch signalling exerts pro-apoptotic effects in B-ALL cells [50].

Thymocyte differentiation begins when bone marrow-derived lymphoid progenitors enter the thymus at the corticomedullary junction and the chemokine receptor CXCR4 (chemokine receptor $\mathrm{C}-\mathrm{X}-\mathrm{C}$ type 4 ) progressively drives their differentiation into mature single-positive thymocytes (SP; $\mathrm{CD} 4^{+} \mathrm{CD}^{+}$), fully competent for immune response in the periphery [55]. Both Notch1 and Notch3, in association with several nuclear factors, regulate these early stages of thymocyte progenitors differentiation $[54,56,57]$.

T-cell acute lymphoblastic leukaemia (T-ALL) is an immature lymphoid tumour characterised by infiltration of the bone marrow by malignant haematopoietic cells expressing immature T-cell markers. The incidence of T-ALL cases is $15 \%$ in children and $25 \%$ in adults and is slightly more frequent in males than in females. Relapses of paediatric T-ALL remains a significant clinical problem [58]. 
T-ALL is the result of a multistep transformation in which accumulating genetic alterations co-ordinately disrupt master developmental pathways responsible for the normal control of immature T-cell growth, proliferation, survival and differentiation [59].

Deregulation of the NOTCH1 or NOTCH3 signalling pathways is intimately involved in the pathogenesis of T-ALL $[60,61]$ and greatly supported by partnership with CXCR4 [62].

More than $50 \%$ of patients with T-ALL have NOTCH1 mutations and MYC has been identified as a key oncogenic mediator of NOTCH1 [63]. Overexpression and more recently activating mutations of Notch3 have been found in a high number of human T-ALL samples [64]. Therefore, targeting Notch is one of the major challenges [65], and treatment strategies that minimize the need for chemotherapy or other targeted anti-leukaemia agents are highly desirable.

\section{Overview of the Immune Mechanisms in T-ALL}

In T-ALL development, abnormal T-lymphoid progenitors invade bone marrow, peripheral blood, and extramedullary sites [50]. The interaction of leukemic cells with the microenvironment within the bone marrow niche is a critical step promoting the progression of T-ALL. The triggering of multiple molecular mechanisms shapes immune cell populations involved in the immune surveillance, such as NK cells, various population of T-cells, including regulatory T-cells (Tregs) and MDSCs $[66,67]$.

NK cells are a population of immune cells that coordinates both the innate and the adaptive response; they constitute $5-15 \%$ of circulating lymphocytes and in various lymphoid and non-lymphoid organs [68]. NK cells have the ability to identify, target and kill cancer cells without prior sensitization. BM is considered to be the primary site of NK development but over the years many studies have reported that NK cells can also develop in secondary lymphoid tissue [68]. The balance between the activating and inhibitory receptors on NK cells and the cognate ligands on ALL cells determines the ability of NK to kill ALL blasts. To escape from NK cell lysis ALL blasts predominantly down-regulate ligands for NK cell-activating receptors $[67,69]$. Patients suffering from ALL have abnormal percentages and absolute numbers of NK cells, as confirmed especially in those diagnosed with T-ALL [70]. More recently, an interesting paper reported that in high-risk patients with B/T-ALL NK cells are unable to lyse NK-sensitive targets with the same efficiency of normal NK cells because have a defective maturation into cytotoxic effectors.. Moreover, an increased frequency of activated cytokine-producing NK cells is associated with disease severity and poor clinical outcomes [71]. Therefore, immunotherapy using NK cells derived from healthy donors may be a more effective therapeutic option, and ongoing protocols try to optimize in vitro NK cell expansion [72].

T-cells are not as effective against cancer as expected, partially because they enter a dysfunctional or exhausted state, mostly triggered by tumour cells, Tregs and MDSC [73]. This may imply sustained expression of inhibitory receptors and a transcriptional program different from that of functional effector and memory T-cells [73]. Indeed, in T-ALL attenuation of T-cell-mediated antitumour immune response may rely on the expression of inhibitory checkpoint receptors on conventional $\mathrm{T}$ cells and on the accumulation and increased suppressive function of Tregs [74].

The involvement of PD1 (programmed death 1) and PDL1 (programmed death ligand 1) in T-ALL is still rarely reported [75]. PD1 expression was observed in tumour infiltrating lymphocytes in approximately $20 \%$ of T-LBL/ALL patients, but absent on their tumour cells of T-LBL/ALL. In contrast, these tumour cells and activated lymphocytes in the reactive lymph nodes from the T-LBL/ALL tissues showed a positive result for PDL1 [75]. Therefore, PDL1 could negatively regulate T-cell activation by binding PD1 to the surface of tumour infiltrating immune cells and promote immune escape.

Furthermore, there are other inhibitory interactions involving leukemic T-cells, such as TIM-3 and its ligand, galectin-9, acting in the inhibition of $\mathrm{CD}^{+} \mathrm{T}$ cell responses in early T-cell precursor ALL [76]. Additionally, in T-ALL even more challenges for strong T-cellmediated immune response/immunotherapies are met [77]. As suggested by Pastorczak 
et al., this can be partly due to the overlap of target antigens between leukemic and normal T-cells, possibly leading to off-target effects [67].

$\mathrm{CD}^{+} \mathrm{CD}^{2} 5^{+} \mathrm{FoxP}^{+}$Tregs, previously known as suppressor T-cells, are immunoregulatory subset of T-lymphocytes that play a crucial role in the maintenance of tolerance to self antigens and the modulation of overall immune responses against infections and tumour cells $[46,78,79]$. A dysregulation or an excess of Tregs could lead to a large type of immune-related diseases and cancers. The regulatory role of Tregs is mediated by various mechanisms: the secretion of the inhibitory cytokines, such as interleukin-10 (IL-10), interleukin-35 (IL-35) and TGF $\beta$; cytolysis of target cells directed by granzyme-A, granzyme-B, and perforin [80]. The potential role of the Notch/NF-kB partnership is also emerging in the generation and function of Tregs in the context of cancer, and more precisely in T-ALL [81]. In haematological malignancies, Treg accumulation is associated with increased tumour progression and suppression of anti-tumour immune responses [82,83]. Rare studies have provided a correlation of Treg number with disease progression and explained how they elicit such a potent suppressive mechanism. Additional functional studies are indeed required. Hence, strategies focused on Treg ablation or selective inactivation are key elements in combination therapies against T-ALL.

In the leukemic microenvironment, macrophages play a role as immune effector cells. Myeloid cells are essential for the homeostasis of the innate and adaptive immune response [84,85]. The pro-tumorigenic function of MDSC is well established in solid tumours and some haematological malignancies, but their role in T-ALL is still poorly understood.

Cancer immunotherapy, which triggers or augments host immune responses to treat haematological malignancies, is the rapidly advancing and innovative approach to cancer immunology.

Tumour-infiltrating NK cells, $\mathrm{T}$ and Treg cells, myeloid cells, including MDSCs are major obstacles to the development of successful cancer immunotherapies. In this regard, in-depth miRNA studies could improve specific immune cell expansions and selective targeting of key components of the immune system to increase anticancer response and to avoid immune surveillance evasion strategies by T-ALL cells.

\section{Biogenesis and Role of miRNAs}

MiRNAs are a class of single-stranded (ss) non-coding RNAs 22 nucleotides long. By binding to the 3' untranslated regions (UTRs) of the target mRNA, they regulate the post-transcriptional gene expression of target genes by influencing the cellular processes to which they are involved.

MicroRNA genes are usually non-coding and found throughout the genome. In some cases, they are also present in introns or in an UTR of a protein coding gene, but generally they are not found in coding exons as its excision would lead to the loss of the protein coding transcript [86].

Starting from a DNA template, RNA polymerase II begins the transcription of an RNA strand, analogous to mRNA, defined as primary miRNA (pri-miRNA).

Primary miRNAs are similar to mRNAs with the cap and polyadenylate sites, but they are also characterized by a hairpin structure recognized by a complex formed by RNase III Drosha and the Di George syndrome critical region gene 8 protein dimer (DGCR8), which recognizes the hairpin stem and cleaves the pri-miRNA producing a pre-miRNA [87].

The structural change allows the binding of the pre-miRNA to the nuclear transport receptor Exportin 5 and Ran GTPase, which translocate the pre-miRNA from the nucleus into the cytoplasm [88]. During the cytoplasmic phase, the DICER enzyme cleaves the precursor loop and forms RNA duplex of $\sim 21$ nucleotides, depending on the miRNA. One strand is loaded into the RISC complex to become mature miRNA, while the other strand is present in the cytoplasm at a lower concentration compared to the guide strand; despite the low concentration, it may also be incorporated into the RISC complex or degraded [89]. 
The peculiarity of miRNA is the seed sequence: a segment from 2 to 8 nucleotides at $5^{\prime}$ complementary to the response element of the miRNA (MRE) located in the 3'UTR of the mRNA. Different mRNAs can have the same MRE and therefore be targets of the same miRNA.

If complementarity is high, miRNA induces degradation of the target mRNA, while if homology is less extensive, they induce translation repression [13].

Over the past decade, many studies have focused attention on the role of miRNAs in cancer-particularly tumour growth, angiogenesis, invasion and immune evasion-by controlling the expression of target mRNAs [90]. Depending on their expression in tumor cells and their role, miRNAs can be divided into two categories: oncogenic-miRNAs and suppressor miRNAs.

Oncogenic miRNAs (onco-miR) are up-regulated in tumour cells and contribute to carcinogenesis by inhibiting tumour suppressor genes. Suppressor miRNAs are downregulated in tumour cells and normally prevent cancer development by inhibiting the expression of proto-oncogenes.

We will now discuss the role of miRNAs in the development of immune cells (NK, T-cells, Tregs and MDSCs) and their deregulation (Table 1) as a potential mechanism of impaired immune response that possibly sustains the maintenance and progression of T-ALL.

\section{5. miRNA and Natural Killer (NK) Cells}

\section{1. miRNA in NK Cell Development: An Overview}

The development of NK cell progenitors progresses through different stages: Stage 1 cells express CD34 but lack CD117, CD94, NKP80, CD16 and the IL-2/IL-15 receptor beta chain [28]. Stage 2 cells are characterized by CD25 (IL-2 receptor), CD122 and CD117. During these two stages, cells also have the capacity to develop into T-cells and dendritic cells (DCs). Stage 3 cells lack the expression of TBX21 (TBET) and Eomesoderm (EOMES) [68]. The transition of NK cells from Stage 2 to Stage 3 is promoted by the expression of activation receptors including NKG2D (Natural Killer Group 2D), CD335, and CD337 [91]. Stage 4 NK cell development is divided into $4 \mathrm{a}$ and $4 \mathrm{~b}$ and identified by the expression of the activating receptor NKp80 [92]. In Stage 4a, the NK cells are NKp80- CD56 ${ }^{\text {bright }}$, while at Stage $4 \mathrm{~b}$, the NK cells become positive for NKp80 and maintain their CD56 $6^{\text {bright }}$ status. In fact, the terminal stages of NK cell development in the blood are dependent on the relative expression of CD56, with the distinction between immature CD56 $6^{\text {bright }}$ and functionally mature CD56 ${ }^{\text {dim }}$ NK cell subsets [91].

To explicate their complete function, NK cells undergo an educational process by contacting "self" major histocompatibility complex (MHC) class I receptors [93]. During tumour invasion, cancer cells down-regulate MHC class I to evade T-cell recognition; this leads to NK cell engagement and activation because of the lack of inhibitory stimulation from binding to killer-cell immunoglobulin-like receptors (KIRs), also called the "missing self" hypothesis [94].

NK cell development is affected by various miRNAs such as miRNA-15/16, miRNA155, miRNA-181 and miRNA-483-3p [28]. In leukemic cell survival, miRNAs-15/16 is inversely correlated with the levels of oncogenes, such as B-cell lymphoma 2 (Bcl2), which is expressed in several haematological diseases [6], myeloid cell leukemia-1 (MCL1), JUN, and WNT3a [95].

Sullivan et al. demonstrated that mice with global deletion of miR-15a/16-1 had defective NK cell maturation with a block in the most mature Stage 4 of murine NK cells $(\mathrm{CD} 27-\mathrm{CD} 11 \mathrm{~b}+)$ and an associated build-up of immature cells (Stage 2 and 3) [96].

This increased amount of immature NK cells was also demonstrated by Trotta et al. using a murine transgenic model with miRNA-155 overexpressed under a lck promoter. These authors showed that higher miRNA-155 expression led to an increase in splenic NK cell numbers with an excess of immature $\left(\mathrm{CD} 11 \mathrm{~b}^{-} \mathrm{CD} 27^{+}\right) \mathrm{NK}$ cells with high cytokine generation but low cytolytic activity [34]. As previously described, NK cell survival 
and maturation are under the control of miRNA-150 and miRNA-181; in fact, mice that overexpressed miRNA-150 had an accumulation of mature hyperfunctional NK cells that may lead to NK cell exhaustion [97].

miR-181 has a central role in regulating the differentiation of B-cells, T-cells and NK cells during normal haematopoiesis [37]. NK cell maturation is promoted by Notch signalling via CD56 acquisition and can also bypass the need for stroma or cytokines like IL-15 to drive NK cell maturation [98].

It has been demonstrated that miR-181 is able to modulate NK cell development through the regulation of Notch signalling by targeting Nemo-like kinase (NLK), an inhibitor of Notch [98]. NLK is regulated by miR-181 specifically on the $3^{\prime}$-UTR. Overexpression of miR-181 down-regulates NLK expression but conversely promotes NK cell development through the Notch signalling pathway. Indeed, miR-181 is also a positive regulator of IFN- $\gamma$, which together with the negative regulator miR-146, balances its expression in NK cells during the immune response [37].

NK cell development could also be modulated by miRNA-483-3p through the downregulation of insulin-like growth factor-1 (IGF-1). Indeed, high exogenous IGF-1 is linked with increased perforin expression in the NK cell, which is critical for cytolytic NK cell function [99].

\section{2. miRNAs Modulate NK Cell Function in T-ALL}

For most of the time, the study of NK cells in the field of leukaemia has been limited to acute myeloid leukaemia (AML) and B-ALL [19]. Little information is related to T-ALL; in fact, some immunotherapies based on NK cells have been proven effective in clinical treatments, especially in AML, but are less promising for T-ALL. The reason is not totally understood, but could be because T-ALL blasts are better for contrasting NK cell cytotoxicity [19].

Although there are more than 100 miRNAs involved in leukemic cells alterations, only few of them directly trigger functional and developmental dysregulation of NK cells. NK cells are important innate immune surveyors that are critical for the removal of leukaemia blasts [100]. T-ALL blasts lead to a reduction on the cell surface of ligands that normally bind NK cell receptors, thus allowing the cells to escape more easily from immunosurveillance control [101].

The biological functions of NK cells and their development are often subject to regulation by microRNAs, and small non-coding RNAs (sncRNAs). The former dysregulate NK cell development and maturation through the deletion of key enzymes in the miRNA biogenesis pathway, such as Dicer and DGCR8. In so doing, mature miRNAs are critical for normal NK-cell homeostasis and activation [102].

For example, microRNA-29b (miR-29b) up-regulation was identified in NK cells in both neurogenic locus notch homolog protein 1 (Notch1)-T-ALL mice and patients with T-ALL. This miRNA is involved in diseases with a severe phenotype; furthermore, it affects the development of NK cells [103].

The expression of miR-29b is higher in NK cells than the level found in T-ALL blasts. This increase is probably due to the vesicular/exosomal release of miR-29b by leukemic blasts as the disease progresses [103]. Further studies of miRNA-29b regulation are needed to fully understand this phenomenon.

Increased levels of miRNA-29b promote decreased cytotoxicity by NK cells in T-ALL. In addition to functionality, NK cell differentiation is also impaired in Notch1-T-ALL and contributes to reduced cytotoxicity by NK cells [18].

Therefore, miRNA-29b turns out to be a crucial partner for leukemic cells in their escape from the surveillance system in T-ALL.

The oncogene Wilms' Tumor 1 (WT1), normally overexpressed in ALL, is also a potential indirect target of miR-15a and miR-16-1; lowering WT1 gene levels promotes the proliferative blockade of leukemic cells [17]. 
On the other hand, miRNAs-15/16 play a key role in the maturation of NK cells and the expression of their function; in this way, they support both the reduction of NK cell cytotoxic capacity and the anti-leukemic effect [95].

Two Notch3 targets, miR-150 and miR-223, regulate NK cell survival, maturation [104] and immune function [68] or specifically control Granzyme B translation in resting NK cells [97], respectively. This would suggest a role for Notch in modulating the immune response in T-ALL.

miR-181a could act as a tumour suppressor in paediatric ALL by over-expressing its target, small mother against decapentaplegic 7 (Smad7) [38], which regulates TGF- $\beta 1$ via negative feedback and mediates the interaction between TGF- $\beta 1$ and other pathways. Moreover, TGF- $\beta 1$ had a role in NK dysfunction in B-ALL blasts, which secrete TGF- $\beta 1$ and use the TGF- $\beta 1 /$ Smad pathway to inhibit NK cytotoxicity [105].

In this way, the functional miR-181-Smad7-TGF- $\beta 1$ relationship may contribute to the discovery of new targets for ALL diagnosis and therapies [38].

Alterations in NK cell maturation and function resulted in decreased NK cytotoxicity in T-ALL, suggesting that these miRNAs are involved in NK cell developmental arrest and functional defects, which are used by leukaemia cells to evade immune surveillance. Further research is required to reveal the mechanism driving this phenomenon and for solutions that restore NK cell maturation and function to decrease T-ALL relapse.

The regulation of NK cell maturation and function by miRNAs may be one of the suitable therapeutic mechanisms for promoting anti-leukemic efficacy.

\section{6. miRNAs and T Cell}

\section{1. miRNAs in T Cell Development: An Overview}

Many excellent articles have revised the role of miRNAs as key regulators in gene expression in immunity and in T-cell development [106,107]. T-lymphocytes, or T-cells, arise from the early T-lineage precursor of the bone marrow that is guided in the thymus to mature and then migrate into peripheral immune tissues to carry out biological functions [106]. In the thymus, the central immune organ, the development of T-cells is divided into several stages according to the expression of CD4 and CD8 coreceptors [108].

Starting from the cortical region, early T-cells gradually differentiate into $\mathrm{CD}^{-} \mathrm{CD}^{-}$ double-negative (DN) cells, and then subsequently divided into four stages (DN1-2-3-4). Under the control of Notch, DN T-cells develop into $\mathrm{CD}^{+} \mathrm{CD}^{+}$double-positive cells (DP), with the expression of the T-cell receptor (TCR), and gradually migrate into the medulla. Mature T-cells express only CD4 or CD8 coreceptors to become single-positive (SP) $\mathrm{CD}^{+}$or $\mathrm{CD}^{+}$. At this point, they migrate to the peripheral lymphoid organs to perform their immune functions. T-cell immunity is influenced by microRNAs that act on the development and function of immune system cells and on related clinical diseases [106].

The miR-17-92 cluster is highly modulated at DN Stage 1 leading to autoimmunity and increased proliferation and survival of T-cells, above all the effector CD4 ${ }^{+}$T-cells [11]. Activation of miR-17-92 by NK like homeodomain proteins suppresses apoptosis in T-ALL by reducing the level of E2F transcription factor 1 (E2F1) [9]. The miR-17-92 cluster blocks the expression of phosphatase and tensin homolog (PTEN) and the pro-apoptotic Bcl-2-like protein 11 (BIM), thereby promoting T-cell survival at the DN2 stage. Furthermore, T-cell survival from the DN to DP stage is influenced by miR-17-92, which regulates IL7R receptor surface expression and response to IL-7 [10].

miR-150 is a hematopoietic-specific miRNA. T-cell development is affected by miR-150, which is overexpressed in mature T- and B-cells. In fact, its expression is at maximum level during the last stages of both B- and T-cell maturation in the bone marrow and thymus, respectively, suggesting that it may participate in B-or T-lymphopoiesis [109].

This miRNA was widely investigated in T-ALL; first, for its role during T-cell development through different stages from DN CD4 ${ }^{-} \mathrm{CD}^{-}$to T-helper [109]; moreover, because miR-150 targets Notch3, its activating mutations are the leading cause of T-ALL $[27,64,110]$. 
The unusual expression of miR-150 has been observed in different haematological malignancies: decreased in lymphoma, chronic myeloid leukaemia (CML) and ALL but increased in chronic lymphocytic leukaemia (CLL) and myelodysplastic syndrome [111]. Indeed, miR-150 exhibited very low expression levels in several T-ALL cell lines. In a study by Ghisi et al., forced expression of miR-150 demonstrated downregulation of Notch3 transcript and dysregulation of biological phenomena, such as inhibition of cell proliferation and induction of cell apoptosis, suggesting its prominent role in T-ALL pathogenesis.

The miR-146b-5p is another of the miRNAs found at high levels in thymocytes in the transition between the DP $\left(\mathrm{CD}^{+} \mathrm{CD}^{+}\right)$to SP stage $\left(\mathrm{CD}^{+}\right.$or $\left.\mathrm{CD} 8^{+}\right)$[26].

miR142-3p is overexpressed in human acute leukaemia T-cells (Jurkat, MOLT-3, MOLT-4) compared to normal counterparts; it has been identified as a haematopoieticspecific miRNA, as it is expressed at different levels of the differentiation stage [25]. The levels of miR-142-3p in leukemic T cells correlate with the prognosis of patients with acute leukaemia. Therefore, its use as a marker in disease outcomes may be advantageous.

The miRNA142-3p also promotes the reduction of cyclic adenosine monophosphate (cAMP) levels and, in this way, interacts with the protein kinase A (PKA) pathway, inducing increased growth of leukemic T-cells. High expression of miR-142-3p characterizes conventional T-cells but not forkhead box P3 (Foxp3 $\left.{ }^{+}\right)$Treg cells; in effector T-cells the miRNA is down-regulated, compared to naive or memory T-cells [25].

miR-223 is among the most up-regulated miRNA in T-ALL [44], and it is a direct target of TAL1 and the Notch-NF-kB axis [43]. TAL1/SCL is part of basic helix-loop-helix (bHLH) family and its expression is aberrant in 60\% of human T-ALL cases [45]. Inhibition of miR223 prevents T-ALL resistance to $\gamma$-secretase inhibitor treatment, suggesting that this inhibition may be exploited in target therapy protocols.

It has been demonstrated that the expression of TAL1 and miR-223 are modulated during the normal T-cell development; miR-223 expression is high in early thymocytes with a down-regulation after the double-negative-2 (DN2) stage of maturation. Furthermore, miR-223 mediates overexpression of TAL1-induced growth of T-ALL cells through the direct inhibition of the expression of the tumour suppressor F-box/WD repeat-containing protein 7 (FBXW7), which has been shown to repress MYC, MYB, NOTCH1, and CYCLIN E expression [112].

One of miR-181 genes family (mir-181ab1, mir-181ab2 and mir-181cd), miR-181ab1 could control how NOTCH acts in tumorigenesis; indeed, miR-181ab1 deletion has an inhibition effect on T-ALL cells. The expression of miR-181a is high at the DP T-cell stage but decreases during development, with almost no expression in differentiated T-cells [113]. Moreover, the effects of this deletion are compensated for during normal thymic progenitor development but not during T-ALL development [45].

\section{2. miRNAs Dysregulate T Cell Immune Response in T-ALL}

As we know, microRNAs are involved in both functional and maturational regulation of several immune cells, in particular T-cells. Several miRNAs are up- and down-regulated during the differentiation process of thymocytes and during related diseases, including ALL [114]. The definitive understanding of their role in T-ALL is still under study.

Among the miRNAs described, it is now clear that miR-29a plays a key role in haematological diseases, such as AML, CLL and T-ALL, albeit less thoroughly [20]. Indeed, this miRNA appears to play a role in leukemogenesis [99], specifically in the pathophysiology of T-ALL.

In 2015, a study by Oliveira et al., allowed a more detailed approach of miRNA-29a with leukemic T cells, which present a very low expression of miR-29a [20].

This miRNA turns out to be very functionally complex: it has DNA methyltransferases DNMT3a and DNMT3b as targets, leading to reduced methylation, but also Cell division protein kinase 6 (CDK6), Peroxidasin-like protein (PXDN), MCL1, CXXC6 (C-X-C motif chemokine receptor 6) in various tumour types and in T-ALL; on the other hand, it is involved in active demethylation through ten-eleven translocation (TET) and Thymine- 
DNA glycosylase (TDG) proteins [81,114]. The family of TET genes (TET1, TET2, and TET3) have been implicated as tumour suppressors in haematological malignancies [115].

Several genes commonly methylated in T-ALL are indeed targeted for demethylation by the action of miRNA [114]. These findings could serve as an input to find new miR-based therapies for leukemias.

One of the first miRNAs discovered in T-ALL pathology is the miR-17-92 cluster, which includes miR-17, miR-18a, miR-19a, miR-20a, miR-19b-1, and miR-92a. Their primary role in leukaemia is to target some of the oncosuppressor genes most involved in T-ALL, such as PTEN, cell cycle inhibitor p21 (CDKN1A) and BCL211 (or BIM) [49].

This miRNAs cluster is overexpressed in T-ALL samples compared with its T-cell counterpart; other miRNAs, which target key T-ALL genes, are differentially modulated, such as miR-223, miR-142-3p, miR-150, miR-93, miR-26a, miR-16, and miR-342 [116].

In T-cell acute lymphoblastic leukaemia for example, the cooperation between miR19 and Notch1 activation has been observed [116]. Indeed, one study reported that the NOTCH1 gene translocation $\mathrm{t}(9 ; 14)(\mathrm{q} 34 ; \mathrm{q} 11)$ was coexistent with the miR-17-92 cluster $\mathrm{t}(13 ; 14)(\mathrm{q} 32 ; \mathrm{q} 11)$ in a leukemic clone. The crosstalk between Notch1 and miR-19 is supported by the correlation between the high number of activating mutations in the Notch1 gene in more than $50 \%$ of leukaemia patients, and the high level of miR-19 in the same patients in T-ALL [117].

miR-19 is a key oncogene in the 17-92 cluster, contributing to the pathogenesis of T-cell leukaemia. In addition, it participates in leukemogenesis, due to its implication in the survival program of T-lymphocytes, via the Phosphoinositide 3-kinases (PI3K) pathway [49]. $\mathrm{PI} 3 \mathrm{~K} / \mathrm{AKT} / \mathrm{mTOR}$ (mechanistic target of rapamycin) pathway is inactivated by the depletion of Circ-PRKDC, a circular (Circ) RNA that has been suggested as a participant in the regulation of cell progression in hematopoietic compartments and is known to interact with RNAs and proteins in malignant conditions. Circ-PRKDC also prevents proliferation and induced autophagy and apoptosis. Circ-PRKDC interacts negatively with miR-653-5p, and the restoration of miR-653-5p prevents T-ALL cell proliferation, while enhancing apoptosis and autophagy [118].

miR-146b-5p is regulated by TAL1, a transcription factor essential for the maintenance and regulation of haematopoiesis. TAL1 is overexpressed in more than $60 \%$ of patients with T-ALL [111]. In so doing, TAL1 inhibits miRNA 146b-5p, constituting a suppressor for solid tumours and hematologic cancers, including T-ALL. The correlation between miR-146b-5p and TAL1, contributes to the pathogenesis of T-ALL, influencing cell migration and leukaemia aggressiveness, but regarding the proliferation of leukemic $\mathrm{T}$ cells, there are no significant effects [119]. T-cell proliferation and apoptosis are also under the control of the expression of miR-325. It is markedly lower and the level of Bcl-2-associated athanogene (BAG2) is markedly higher in patients with T-ALL and in T-ALL cell lines; BAG2 knockdown can influence cell proliferation and apoptosis and miR-325 shares a binding site with BAG2. miR-325 has an inhibitory effect on the proliferation of cancer cells. Additionally, the biological effects of miR-325 on the proliferation and apoptosis of Jurkat cells were reversed by the introduction of BAG2 [46].

In the context of T-cell leukaemia, an attractive hypothesis is that leukemic cells could release exosome-directed miRNAs intending to suppress specific immune cells. This could be suggested by the expression of some miRNAs, such as the Notch3-regulated miR-150, common to T, Treg, and NK cell microenvironments, or the case of miR-29 and miR-181 common to $\mathrm{T}$ and NK cells. Indeed, this mechanism has been suggested since miR150 is abundant in plasma-derived exosomes in the microenvironment of AML and CLL patients [78,79] and is possibly associated with impaired NK cell function [97].

\subsection{The Modulatory Role of miRNAs in Treg Cell Function in T-ALL}

The transcription factor Foxp3 is highly and specifically expressed in Tregs, which are characterized as the $\mathrm{CD}^{+} \mathrm{CD}^{+} 5^{+}$Foxp $3^{+}$T lymphocytes [120]. 
In 2006, Cobb et al. identified 35 microRNAs that were up-regulated in Tregs, including miR-223, miR-146, miR-21, miR-22, miR-23a and b, miR-24, miR-214, and miR-155 and 33 microRNAs that were down-regulated, including miR-142-5p and miR-142-3p, miR-30b, miR-30c, miR-30e [121].

miR-155 targets FOXP3, which might regulate Treg cell differentiation and function. One study refers the reduction in miR-155 level in ALL patients compared to controls; particularly, miR-155 can act as a modulator of Treg cells differentiation by targeting Suppressor Of Cytokine Signaling 1 (SOCS1) [36]. In so doing, miR-155 could affect IL2 signalling by inhibiting SOCS1 expression to regulate Treg proliferation [31]. Loss of miR-155 can also contribute to B-cell malignancies [33,35].

Several cytokines contribute to Treg regulation and differentiation, including IL-6, IL-17, IL-23, Tumor necrosis factor $\alpha$ (TNF- $\alpha)$, TGF- $\beta$ and IL-10 [12]. Through the inhibition of programmed cell death protein 4 (PDCD4), IL-10 can specifically down-regulate miR-155; on the other hand, IL-10 can be induced by miR-21 [12]. Knowing that IL-10 and miR-21 are significantly elevated in ALL patients, it was suggested that the slight elevation in Treg cells in the patients' group might be tightened as a result of the reduction of miR-155. Treg cells exert their immunosuppressive effects via IL-10 release leading to inefficient control of inflammation, which favours paediatric ALL progression [12].

miR-26a and miR-133b are down-regulated in ALL patients compared to controls. miR26a is found to promote Treg production and up-regulate Treg cell function by targeting IL-6. This is an inflammatory cytokine that has a crucial role in the inhibition of Treg functions [16], while miR-133b was reported within a cluster of miR-206 to be responsible for IL-17A gene co-expression [24]. These data presented by Haas et al. (2011) agree with the reduction in both miR-133b and IL-17 expression levels in ALL patients [122].

The cytokine alteration induced by miRNAs during the differentiation of Treg cells could possibly be involved in the pathogenesis of ALL. Other investigations are needed to get a better understanding of the pathologic role of selected miRNAs and their interplaying role with pro-/anti-inflammatory cytokines in ALL.

\section{MDSCs and Tregs}

MDSCs and Treg cells are immunoregulatory cells of the tumour microenvironment in solid tumours and haematological malignancies [123,124].

Only a few studies have characterized MDSC and Treg cells based on some miRNA expression profiles in cancer, and were recently reviewed in [125]. This could be useful for identifying reliable biomarkers in cancer, particularly in ALL [124].

A study found that 12 miRNAs (17.4\%) are common among MDSC and Treg cells in ALL patients (miR-10a-5p, -16-2-3p, -21-3p, -21-5p, -145-5p, -146a-5p, -150-3p, 155-5p, $-155-5 p,-210-3 p,-210-5 p)$. They might be involved in 4 immune-related pathways: TNF, TGF- $\beta$, Forkhead box O (FoxO) and Hippo. Moreover, some of these common miRNAs modulate the differentiation and the immunomodulation functions of MDSC and Treg cells [7], or even NK maturation and cytolytic activity as is the case of miR-155 [34] as shown in Figure 1. For example, miR-16-2-3p seems to block the function of MDSC and Treg cells in the tumour microenvironment via the inhibition of the PD-L1/PD-1 signalling pathway [8].

Up-regulation of miR-210 in pediatric ALL patients may be linked with the miR-210modulated immunosuppressive activity of tumor MDSC sy increased arginase activity and nitric oxide production, as induced by hypoxia $[41,126]$.

In addition, up-regulation of miR-34a-5p promotes the expansion of MDSCs and the mechanism through which cell surface-associated MUC1 (Mucin 1, cell surface associated) drives c-Myc expression during the leukemogenesis in AML [23]. This is in contrast with a study by Salem et al., where miR-34a-5p was found to be down-regulated in ALL [7]. 


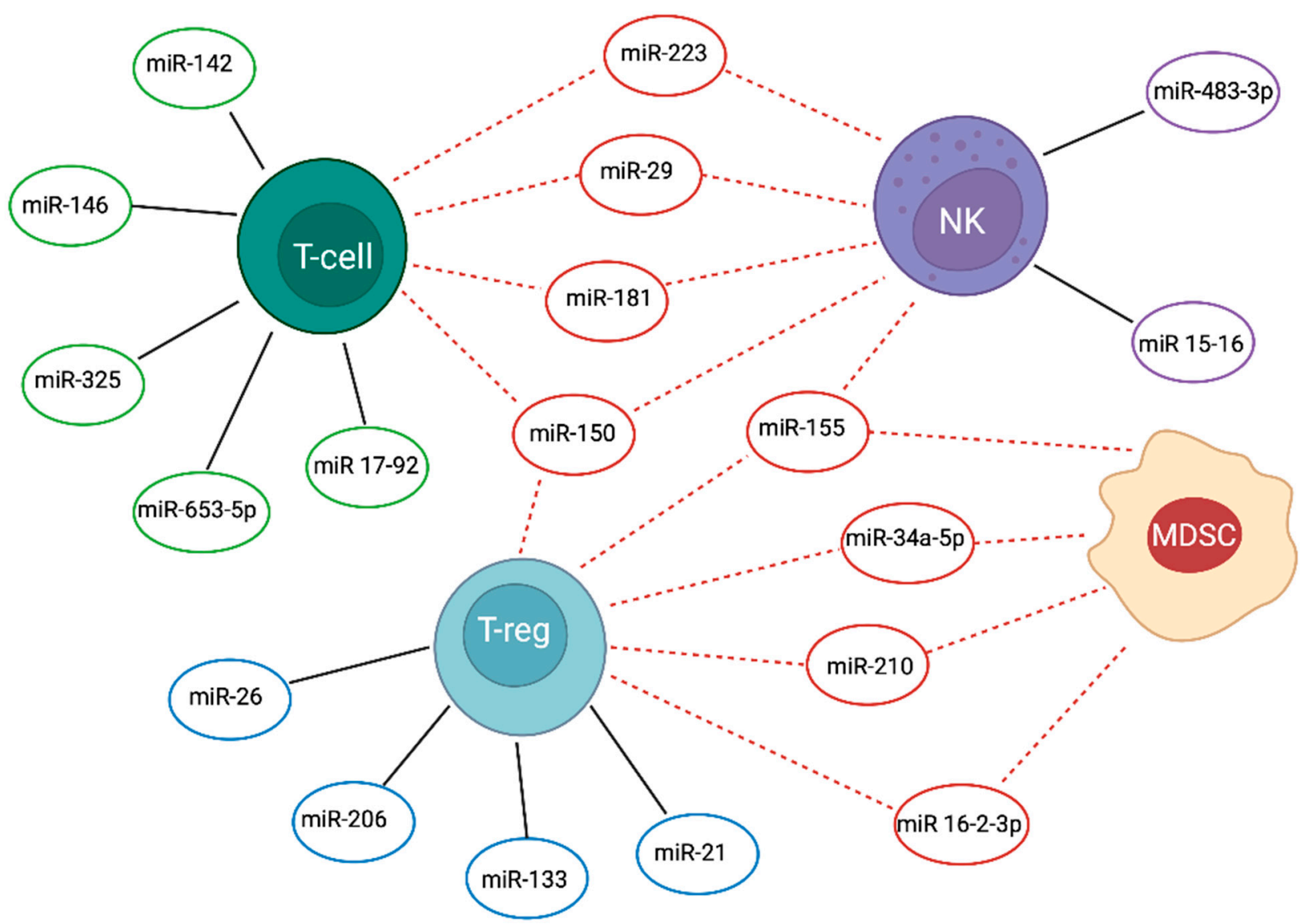

Figure 1. Common and cell-specific miRNAs in immune cell responders against ALL. Common (dotted-line-) and cell-specific (black line-) miRNAs are depicted in the figure in association with the Natural Killer (NK), T and T-regulatory (Treg), and myeloid derived suppressor (MDSC) cells. Created by Biorender.com.

Targeting MDSC can represent a future challenge in modulating immunosuppressive functions in tumour microenvironment.

Still poorly understood is the role of MDSC in ALL, but the acquisition of more knowledge about miRNA tuning could improve the possible application as a therapy.

\section{Conclusions and Future Perspectives}

Some miRNAs have been shown to regulate both lymphoid and myeloid cell lineage of the haematopoietic system and the key role of miRNA-mediated gene regulation has been established in the immune system. However, there are still many unresolved questions concerning how immune cells modulate this process during the anti-leukaemia immune response and how their deregulation may contribute to leukemogenesis. Additionally, the effect of one miRNA on many transcripts of genes often with related function gives complexity to the system.

The expression signatures of miRNAs are distinct in the differentiation and maturation of the haematopoietic cell lineage and this may be useful in distinguishing Acute Lymphoblastic Leukaemia from Acute Myeloid Leukaemia with 97\% accuracy [127]. Moreover, evidence suggests that miRNAs can be used as potential diagnostic and prognostic biomarkers in B-ALL [128]. Diagnostics for haematological malignancies are performed on peripheral blood and bone marrow samples and are based on cytogenetic analysis of the morphological, cytochemical and immunophenotypic characteristics of the cell lineage. To date, in comparison to B-ALL, no miRNA has prognostic or diagnostic value in T-ALL, which is an intensive area of research. Notwithstanding its side effects, intensive chemotherapy still represents the best therapeutic option for T-ALL. Therefore, the characterization 
of the leukemic microenvironment concerning miRNA-based modulation of immune responses could pave the way for a combination of miRNA-related immunotherapies with conventional cytotoxic drugs or targeted therapy. This is also a valuable opportunity for effective therapeutic intervention for relapsing patients of T-ALL.

To be further analysed, is the release mechanism of selected miRNAs in the extracellular space, thus contributing to the ability of T-ALL cells to control trafficking of regulatory molecules within the leukemic microenvironment. This intercellular crosstalk could be the way to modulate immune cell function and be a new approach to target anomalous immune response in leukaemia. Accordingly, exosome- and immune cell-based delivery could represent two interesting strategies for miRNA-based cancer immunotherapy.

Funding: This work has been supported by the Italian Ministry of Education, University and ResearchDipartimenti di Eccellenza, L. 232/2016; by Sapienza University, Ateneo 2019 (RP11916B88BC2710) to MPF.

Conflicts of Interest: The authors declare no conflict of interest.

\section{References}

1. Jia, Y.; Wei, Y. Modulators of MicroRNA Function in the Immune System. Int. J. Mol. Sci. 2020, 21, 2357. [CrossRef] [PubMed]

2. Ha, M.; Kim, V.N. Regulation of microRNA biogenesis. Nat. Rev. Mol. Cell Biol. 2014, 15, 509-524. [CrossRef]

3. Ansel, K.M. RNA regulation of the immune system. Immunol. Rev. 2013, 253, 5-11. [CrossRef] [PubMed]

4. Schetter, A.J.; Heegaard, N.H.; Harris, C.C. Inflammation and cancer: Interweaving microRNA, free radical, cytokine and p53 pathways. Carcinogenesis 2010, 31, 37-49. [CrossRef] [PubMed]

5. Tili, E.; Michaille, J.J.; Croce, C.M. MicroRNAs play a central role in molecular dysfunctions linking inflammation with cancer. Immunol. Rev. 2013, 253, 167-184. [CrossRef] [PubMed]

6. Cimmino, A.; Calin, G.A.; Fabbri, M.; Iorio, M.V.; Ferracin, M.; Shimizu, M.; Wojcik, S.E.; Aqeilan, R.I.; Zupo, S.; Dono, M.; et al. miR-15 and miR-16 induce apoptosis by targeting BCL2. Proc. Natl. Acad. Sci. USA 2005, 102, 13944-13949. [CrossRef] [PubMed]

7. Salem, M.L.; Zidan, A.A.; El-Naggar, R.E.E.-D.; Saad, M.A.; El-Shanshory, M.; Bakry, U.; Zidan, M. Myeloid-derived suppressor cells and regulatory $\mathrm{T}$ cells share common immunoregulatory pathways-related microRNAs that are dysregulated by acute lymphoblastic leukemia and chemotherapy. Hum. Immunol. 2021, 82, 36-45. [CrossRef] [PubMed]

8. Su, Y.; Qiu, Y.; Qiu, Z.; Qu, P. MicroRNA networks regulate the differentiation, expansion and suppression function of myeloidderived suppressor cells in tumor microenvironment. J. Cancer 2019, 10, 4350-4356. [CrossRef] [PubMed]

9. Nagel, S.; Venturini, L.; Przybylski, G.K.; Grabarczyk, P.; Schmidt, C.A.; Meyer, C.; Drexler, H.G.; Macleod, R.A.; Scherr, M. Activation of miR-17-92 by NK-like homeodomain proteins suppresses apoptosis via reduction of E2F1 in T-cell acute lymphoblastic leukemia. Leuk Lymphoma 2009, 50, 101-108. [CrossRef] [PubMed]

10. Regelin, M.; Blume, J.; Pommerencke, J.; Vakilzadeh, R.; Witzlau, K.; Lyszkiewicz, M.; Zietara, N.; Saran, N.; Schambach, A.; Krueger, A. Responsiveness of Developing T Cells to IL-7 Signals Is Sustained by miR-17 approximately 92. J. Immunol. 2015, 195, 4832-4840. [CrossRef]

11. Tsitsiou, E.; Lindsay, M.A. microRNAs and the immune response. Curr. Opin. Pharmacol. 2009, 9, 514-520. [CrossRef] [PubMed]

12. El-Maadawy, E.A.; Elshal, M.F.; Bakry, R.M.; Moussa, M.M.; El-Naby, S.; Talaat, R.M. Regulation of CD4(+)CD25(+)FOXP3(+) cells in Pediatric Acute Lymphoblastic Leukemia (ALL): Implication of cytokines and miRNAs. Mol. Immunol. 2020, 124, 1-8. [CrossRef]

13. Junker, F.; Chabloz, A.; Koch, U.; Radtke, F. Dicer1 imparts essential survival cues in Notch-driven T-ALL via miR-21-mediated tumor suppressor Pdcd4 repression. Blood 2015, 126, 993-1004. [CrossRef] [PubMed]

14. Quinn, S.R.; O'Neill, L.A. The role of microRNAs in the control and mechanism of action of IL-10. Curr. Top. Microbiol. Immunol. 2014, 380, 145-155. [CrossRef]

15. Yuan, T.; Yang, Y.; Chen, J.; Li, W.; Li, W.; Zhang, Q.; Mi, Y.; Goswami, R.S.; You, J.Q.; Lin, D.; et al. Regulation of PI3K signaling in T-cell acute lymphoblastic leukemia: A novel PTEN/Ikaros/miR-26b mechanism reveals a critical targetable role for PIK3CD. Leukemia 2017, 31, 2355-2364. [CrossRef] [PubMed]

16. Zhang, R.; Tian, A.; Wang, J.; Shen, X.; Qi, G.; Tang, Y. miR26a modulates Th17/T reg balance in the EAE model of multiple sclerosis by targeting IL6. Neuromolecular Med. 2015, 17, 24-34. [CrossRef] [PubMed]

17. Huan, J.; Hornick, N.I.; Shurtleff, M.J.; Skinner, A.M.; Goloviznina, N.A.; Roberts, C.T., Jr.; Kurre, P. RNA trafficking by acute myelogenous leukemia exosomes. Cancer Res. 2013, 73, 918-929. [CrossRef]

18. Jin, F.; Du, Z.; Tang, Y.; Wang, L.; Yang, Y. Impact of microRNA-29b on natural killer cells in T-cell acute lymphoblastic leukemia. Oncol. Lett. 2019, 18, 2394-2403. [CrossRef] [PubMed]

19. Lion, E.; Willemen, Y.; Berneman, Z.N.; Van Tendeloo, V.F.; Smits, E.L. Natural killer cell immune escape in acute myeloid leukemia. Leukemia 2012, 26, 2019-2026. [CrossRef] 
20. Oliveira, L.H.; Schiavinato, J.L.; Fraguas, M.S.; Lucena-Araujo, A.R.; Haddad, R.; Araujo, A.G.; Dalmazzo, L.F.; Rego, E.M.; Covas, D.T.; Zago, M.A.; et al. Potential roles of microRNA-29a in the molecular pathophysiology of T-cell acute lymphoblastic leukemia. Cancer Sci. 2015, 106, 1264-1277. [CrossRef]

21. Hart, M.; Rheinheimer, S.; Leidinger, P.; Backes, C.; Menegatti, J.; Fehlmann, T.; Grasser, F.; Keller, A.; Meese, E. Identification of miR-34a-target interactions by a combined network based and experimental approach. Oncotarget 2016, 7, 34288-34299. [CrossRef] [PubMed]

22. Hart, M.; Walch-Ruckheim, B.; Friedmann, K.S.; Rheinheimer, S.; Tanzer, T.; Glombitza, B.; Sester, M.; Lenhof, H.P.; Hoth, M.; Schwarz, E.C.; et al. miR-34a: A new player in the regulation of T cell function by modulation of NF-kappaB signaling. Cell Death Dis. 2019, 10, 46. [CrossRef] [PubMed]

23. Pyzer, A.R.; Stroopinsky, D.; Rajabi, H.; Washington, A.; Tagde, A.; Coll, M.; Fung, J.; Bryant, M.P.; Cole, L.; Palmer, K.; et al. MUC1-mediated induction of myeloid-derived suppressor cells in patients with acute myeloid leukemia. Blood 2017, 129, 1791-1801. [CrossRef]

24. Podshivalova, K.; Salomon, D.R. MicroRNA regulation of T-lymphocyte immunity: Modulation of molecular networks responsible for T-cell activation, differentiation, and development. Crit. Rev. Immunol. 2013, 33, 435-476. [CrossRef]

25. Lv, M.; Zhang, X.; Jia, H.; Li, D.; Zhang, B.; Zhang, H.; Hong, M.; Jiang, T.; Jiang, Q.; Lu, J.; et al. An oncogenic role of miR-142-3p in human T-cell acute lymphoblastic leukemia (T-ALL) by targeting glucocorticoid receptor-alpha and cAMP/PKA pathways. Leukemia 2012, 26, 769-777. [CrossRef]

26. Correia, N.C.; Fragoso, R.; Carvalho, T.; Enguita, F.J.; Barata, J.T. MiR-146b negatively regulates migration and delays progression of T-cell acute lymphoblastic leukemia. Sci. Rep. 2016, 6, 31894. [CrossRef]

27. Ghisi, M.; Corradin, A.; Basso, K.; Frasson, C.; Serafin, V.; Mukherjee, S.; Mussolin, L.; Ruggero, K.; Bonanno, L.; Guffanti, A.; et al. Modulation of microRNA expression in human T-cell development: Targeting of NOTCH3 by miR-150. Blood 2011, 117, 7053-7062. [CrossRef]

28. Saultz, J.N.; Freud, A.G.; Mundy-Bosse, B.L. MicroRNA regulation of natural killer cell development and function in leukemia. Mol. Immunol. 2019, 115, 12-20. [CrossRef]

29. Warth, S.C.; Hoefig, K.P.; Hiekel, A.; Schallenberg, S.; Jovanovic, K.; Klein, L.; Kretschmer, K.; Ansel, K.M.; Heissmeyer, V. Induced miR-99a expression represses Mtor cooperatively with miR-150 to promote regulatory T-cell differentiation. EMBO J. 2015, 34, 1195-1213. [CrossRef]

30. Li, L.; Zhang, J.; Diao, W.; Wang, D.; Wei, Y.; Zhang, C.Y.; Zen, K. MicroRNA-155 and MicroRNA-21 promote the expansion of functional myeloid-derived suppressor cells. J. Immunol. 2014, 192, 1034-1043. [CrossRef]

31. Liu, C.; Li, N.; Liu, G. The Role of MicroRNAs in Regulatory T Cells. J. Immunol. Res. 2020, 2020, 3232061. [CrossRef]

32. O'Connell, R.M.; Kahn, D.; Gibson, W.S.; Round, J.L.; Scholz, R.L.; Chaudhuri, A.A.; Kahn, M.E.; Rao, D.S.; Baltimore, D. MicroRNA-155 promotes autoimmune inflammation by enhancing inflammatory T cell development. Immunity 2010, 33, 607-619. [CrossRef]

33. Thai, T.H.; Calado, D.P.; Casola, S.; Ansel, K.M.; Xiao, C.; Xue, Y.; Murphy, A.; Frendewey, D.; Valenzuela, D.; Kutok, J.L.; et al. Regulation of the germinal center response by microRNA-155. Science 2007, 316, 604-608. [CrossRef]

34. Trotta, R.; Chen, L.; Ciarlariello, D.; Josyula, S.; Mao, C.; Costinean, S.; Yu, L.; Butchar, J.P.; Tridandapani, S.; Croce, C.M.; et al. miR-155 regulates IFN-gamma production in natural killer cells. Blood 2012, 119, 3478-3485. [CrossRef]

35. Vigorito, E.; Perks, K.L.; Abreu-Goodger, C.; Bunting, S.; Xiang, Z.; Kohlhaas, S.; Das, P.P.; Miska, E.A.; Rodriguez, A.; Bradley, A.; et al. microRNA-155 regulates the generation of immunoglobulin class-switched plasma cells. Immunity 2007, 27, 847-859. [CrossRef]

36. Yao, R.; Ma, Y.L.; Liang, W.; Li, H.H.; Ma, Z.J.; Yu, X.; Liao, Y.H. MicroRNA-155 modulates Treg and Th17 cells differentiation and Th17 cell function by targeting SOCS1. PLOS ONE 2012, 7, e46082. [CrossRef]

37. Cichocki, F.; Felices, M.; McCullar, V.; Presnell, S.R.; Al-Attar, A.; Lutz, C.T.; Miller, J.S. Cutting edge: microRNA-181 promotes human NK cell development by regulating Notch signaling. J. Immunol. 2011, 187, 6171-6175. [CrossRef]

38. Nabhan, M.; Louka, M.L.; Khairy, E.; Tash, F.; Ali-Labib, R.; El-Habashy, S. MicroRNA-181a and its target Smad 7 as potential biomarkers for tracking child acute lymphoblastic leukemia. Gene 2017, 628, 253-258. [CrossRef] [PubMed]

39. Wallaert, A.; Van Loocke, W.; Hernandez, L.; Taghon, T.; Speleman, F.; Van Vlierberghe, P. Comprehensive miRNA expression profiling in human T-cell acute lymphoblastic leukemia by small RNA-sequencing. Sci. Rep. 2017, 7, 7901. [CrossRef]

40. Mei, Y.; Gao, C.; Wang, K.; Cui, L.; Li, W.; Zhao, X.; Liu, F.; Wu, M.; Deng, G.; Ding, W.; et al. Effect of microRNA-210 on prognosis and response to chemotherapeutic drugs in pediatric acute lymphoblastic leukemia. Cancer Sci. 2014, 105, 463-472. [CrossRef] [PubMed]

41. Noman, M.Z.; Janji, B.; Hu, S.; Wu, J.C.; Martelli, F.; Bronte, V.; Chouaib, S. Tumor-Promoting Effects of Myeloid-Derived Suppressor Cells Are Potentiated by Hypoxia-Induced Expression of miR-210. Cancer Res. 2015, 75, 3771-3787. [CrossRef]

42. Begley, C.G.; Aplan, P.D.; Davey, M.P.; Nakahara, K.; Tchorz, K.; Kurtzberg, J.; Hershfield, M.S.; Haynes, B.F.; Cohen, D.I.; Waldmann, T.A.; et al. Chromosomal translocation in a human leukemic stem-cell line disrupts the T-cell antigen receptor delta-chain diversity region and results in a previously unreported fusion transcript. Proc. Natl. Acad. Sci. USA 1989, 86, 2031-2035. [CrossRef] 
43. Kumar, V.; Palermo, R.; Talora, C.; Campese, A.F.; Checquolo, S.; Bellavia, D.; Tottone, L.; Testa, G.; Miele, E.; Indraccolo, S.; et al. Notch and NF-kB signaling pathways regulate miR-223/FBXW7 axis in T-cell acute lymphoblastic leukemia. Leukemia 2014, 28, 2324-2335. [CrossRef]

44. Shu, Y.; Wang, Y.; Lv, W.Q.; Peng, D.Y.; Li, J.; Zhang, H.; Jiang, G.J.; Yang, B.J.; Liu, S.; Zhang, J.; et al. ARRB1-Promoted NOTCH1 Degradation Is Suppressed by OncomiR miR-223 in T-cell Acute Lymphoblastic Leukemia. Cancer Res. 2020, 80, 988-998. [CrossRef] [PubMed]

45. Ye, F. MicroRNA expression and activity in T-cell acute lymphoblastic leukemia. Oncotarget 2018, 9, 5445-5458. [CrossRef] [PubMed]

46. Wang, F.; Wang, F.; Zhang, S.; Xu, X. MicroRNA-325 inhibits the proliferation and induces the apoptosis of T cell acute lymphoblastic leukemia cells in a BAG2-dependent manner. Exp. Ther. Med. 2021, 21, 631. [CrossRef]

47. Li, W.Y.; Chen, X.M.; Xiong, W.; Guo, D.M.; Lu, L.; Li, H.Y. Detection of microvesicle miRNA expression in ALL subtypes and analysis of their functional roles. J. Huazhong Univ. Sci. Technol. Med. Sci. 2014, 34, 640-645. [CrossRef] [PubMed]

48. Ni, F.; Guo, C.; Sun, R.; Fu, B.; Yang, Y.; Wu, L.; Ren, S.; Tian, Z.; Wei, H. MicroRNA transcriptomes of distinct human NK cell populations identify miR-362-5p as an essential regulator of NK cell function. Sci. Rep. 2015, 5, 9993. [CrossRef] [PubMed]

49. Mavrakis, K.J.; Van Der Meulen, J.; Wolfe, A.L.; Liu, X.; Mets, E.; Taghon, T.; Khan, A.A.; Setty, M.; Rondou, P.; Vandenberghe, P.; et al. A cooperative microRNA-tumor suppressor gene network in acute T-cell lymphoblastic leukemia (T-ALL). Nat. Genet. 2011, 43, 673-678. [CrossRef]

50. Chiaretti, S.; Vitale, A.; Cazzaniga, G.; Orlando, S.M.; Silvestri, D.; Fazi, P.; Valsecchi, M.G.; Elia, L.; Testi, A.M.; Mancini, F.; et al. Clinico-biological features of 5202 patients with acute lymphoblastic leukemia enrolled in the Italian AIEOP and GIMEMA protocols and stratified in age cohorts. Haematologica 2013, 98, 1702-1710. [CrossRef]

51. Guruharsha, K.G.; Kankel, M.W.; Artavanis-Tsakonas, S. The Notch signalling system: Recent insights into the complexity of a conserved pathway. Nat. Rev. Genet. 2012, 13, 654-666. [CrossRef] [PubMed]

52. Giaimo, B.D.; Borggrefe, T. Introduction to Molecular Mechanisms in Notch Signal Transduction and Disease Pathogenesis. Adv. Exp. Med. Biol. 2018, 1066, 3-30. [CrossRef] [PubMed]

53. Zema, S.; Pelullo, M.; Nardozza, F.; Felli, M.P.; Screpanti, I.; Bellavia, D. A Dynamic Role of Mastermind-Like 1: A Journey Through the Main (Path)ways Between Development and Cancer. Front. Cell Dev. Biol. 2020, 8, 613557. [CrossRef] [PubMed]

54. Tsaouli, G.; Barbarulo, A.; Vacca, A.; Screpanti, I.; Felli, M.P. Molecular Mechanisms of Notch Signaling in Lymphoid Cell Lineages Development: NF-kappaB and Beyond. Adv. Exp. Med. Biol. 2020, 1227, 145-164. [CrossRef] [PubMed]

55. Gleimer, M.; von Boehmer, H. Thymocyte selection: Chemokine signaling is not only about the destination. Curr. Biol. 2010, 20, R316-R318. [CrossRef] [PubMed]

56. Felli, M.P.; Maroder, M.; Mitsiadis, T.A.; Campese, A.F.; Bellavia, D.; Vacca, A.; Mann, R.S.; Frati, L.; Lendahl, U.; Gulino, A.; et al. Expression pattern of notch1, 2 and 3 and Jagged1 and 2 in lymphoid and stromal thymus components: Distinct ligand-receptor interactions in intrathymic T cell development. Int. Immunol. 1999, 11, 1017-1025. [CrossRef]

57. Yashiro-Ohtani, Y.; Ohtani, T.; Pear, W.S. Notch regulation of early thymocyte development. Semin. Immunol. 2010, 22, 261-269. [CrossRef]

58. Kannan, S.; Aitken, M.J.L.; Herbrich, S.M.; Golfman, L.S.; Hall, M.G.; Mak, D.H.; Burks, J.K.; Song, G.; Konopleva, M.; Mullighan, C.G.; et al. Antileukemia Effects of Notch-Mediated Inhibition of Oncogenic PLK1 in B-Cell Acute Lymphoblastic Leukemia. Mol. Cancer Ther. 2019, 18, 1615-1627. [CrossRef]

59. Girardi, T.; Vicente, C.; Cools, J.; De Keersmaecker, K. The genetics and molecular biology of T-ALL. Blood 2017, 129, 1113-1123. [CrossRef]

60. Bellavia, D.; Campese, A.F.; Alesse, E.; Vacca, A.; Felli, M.P.; Balestri, A.; Stoppacciaro, A.; Tiveron, C.; Tatangelo, L.; Giovarelli, M.; et al. Constitutive activation of NF-kappaB and T-cell leukemia/lymphoma in Notch3 transgenic mice. EMBO J. 2000, 19, 3337-3348. [CrossRef]

61. Palomero, T.; Ferrando, A. Therapeutic targeting of NOTCH1 signaling in T-cell acute lymphoblastic leukemia. Clin. Lymphoma Myeloma 2009, 9, S205-S210. [CrossRef] [PubMed]

62. Tsaouli, G.; Ferretti, E.; Bellavia, D.; Vacca, A.; Felli, M.P. Notch/CXCR4 Partnership in Acute Lymphoblastic Leukemia Progression. J. Immunol. Res. 2019, 2019, 5601396. [CrossRef] [PubMed]

63. Belver, L.; Ferrando, A. The genetics and mechanisms of T cell acute lymphoblastic leukaemia. Nat. Rev. Cancer 2016, 16, 494-507. [CrossRef] [PubMed]

64. Bernasconi-Elias, P.; Hu, T.; Jenkins, D.; Firestone, B.; Gans, S.; Kurth, E.; Capodieci, P.; Deplazes-Lauber, J.; Petropoulos, K.; Thiel, P.; et al. Characterization of activating mutations of NOTCH3 in T-cell acute lymphoblastic leukemia and anti-leukemic activity of NOTCH3 inhibitory antibodies. Oncogene 2016, 35, 6077-6086. [CrossRef]

65. Zhdanovskaya, N.; Firrincieli, M.; Lazzari, S.; Pace, E.; Rossi, P.S.; Felli, M.P.; Talora, C.; Screpanti, I.; Palermo, R. Targeting Notch to Maximize Chemotherapeutic Benefits: Rationale, Advanced Strategies, and Future Perspectives. Cancers 2021, 13, 5106. [CrossRef] [PubMed]

66. Ferrandino, F.; Grazioli, P.; Bellavia, D.; Campese, A.F.; Screpanti, I.; Felli, M.P. Notch and NF-kappaB: Coach and Players of Regulatory T-Cell Response in Cancer. Front. Immunol. 2018, 9, 2165. [CrossRef] [PubMed]

67. Pastorczak, A.; Domka, K.; Fidyt, K.; Poprzeczko, M.; Firczuk, M. Mechanisms of Immune Evasion in Acute Lymphoblastic Leukemia. Cancers 2021, 13, 1536. [CrossRef] [PubMed] 
68. Liu, S.; Galat, V.; Galat, Y.; Lee, Y.K.A.; Wainwright, D.; Wu, J. NK cell-based cancer immunotherapy: From basic biology to clinical development. J. Hematol. Oncol. 2021, 14, 7. [CrossRef]

69. Moretta, L.; Montaldo, E.; Vacca, P.; Del Zotto, G.; Moretta, F.; Merli, P.; Locatelli, F.; Mingari, M.C. Human natural killer cells: Origin, receptors, function, and clinical applications. Int. Arch. Allergy Immunol. 2014, 164, 253-264. [CrossRef]

70. Valenzuela-Vazquez, L.; Nunez-Enriquez, J.C.; Sanchez-Herrera, J.; Jimenez-Hernandez, E.; Martin-Trejo, J.A.; EspinozaHernandez, L.E.; Medina-Sanson, A.; Flores-Villegas, L.V.; Penaloza-Gonzalez, J.G.; Refugio Torres-Nava, J.; et al. Functional characterization of NK cells in Mexican pediatric patients with acute lymphoblastic leukemia: Report from the Mexican Interinstitutional Group for the Identification of the Causes of Childhood Leukemia. PLoS ONE 2020, 15, e0227314. [CrossRef]

71. Duault, C.; Kumar, A.; Khani, A.T.; Lee, S.J.; Yang, L.; Huang, M.; Hurtz, C.; Manning, B.; Ghoda, L.; McDonald, T.; et al. Activated natural killer cells predict poor clinical prognosis in high-risk B- and T-cell acute lymphoblastic leukemia. Blood 2021, 138, 1465-1480. [CrossRef]

72. Liu, L.L.; Beziat, V.; Oei, V.Y.S.; Pfefferle, A.; Schaffer, M.; Lehmann, S.; Hellstrom-Lindberg, E.; Soderhall, S.; Heyman, M.; Grander, D.; et al. Ex Vivo Expanded Adaptive NK Cells Effectively Kill Primary Acute Lymphoblastic Leukemia Cells. Cancer Immunol. Res. 2017, 5, 654-665. [CrossRef] [PubMed]

73. Zhang, Z.; Liu, S.; Zhang, B.; Qiao, L.; Zhang, Y.; Zhang, Y. T Cell Dysfunction and Exhaustion in Cancer. Front. Cell Dev. Biol. 2020, 8, 17. [CrossRef]

74. Kang, S.H.; Hwang, H.J.; Yoo, J.W.; Kim, H.; Choi, E.S.; Hwang, S.H.; Cho, Y.U.; Jang, S.; Park, C.J.; Im, H.J.; et al. Expression of Immune Checkpoint Receptors on T-Cells and Their Ligands on Leukemia Blasts in Childhood Acute Leukemia. Anticancer. Res. 2019, 39, 5531-5539. [CrossRef] [PubMed]

75. Yang, K.; Xu, J.; Liu, Q.; Li, J.; Xi, Y. Expression and significance of CD47, PD1 and PDL1 in T-cell acute lymphoblastic lymphoma/leukemia. Pathol. Res. Pract. 2019, 215, 265-271. [CrossRef] [PubMed]

76. Anand, P.; Guillaumet-Adkins, A.; Dimitrova, V.; Yun, H.; Drier, Y.; Sotudeh, N.; Rogers, A.; Ouseph, M.M.; Nair, M.; Potdar, S.; et al. Single-cell RNA-seq reveals developmental plasticity with coexisting oncogenic states and immune evasion programs in ETP-ALL. Blood 2021, 137, 2463-2480. [CrossRef] [PubMed]

77. Bayon-Calderon, F.; Toribio, M.L.; Gonzalez-Garcia, S. Facts and Challenges in Immunotherapy for T-Cell Acute Lymphoblastic Leukemia. Int. J. Mol. Sci. 2020, 21, 7685. [CrossRef] [PubMed]

78. Hornick, N.I.; Doron, B.; Abdelhamed, S.; Huan, J.; Harrington, C.A.; Shen, R.; Cambronne, X.A.; Verghese, S.C.; Kurre, P. AML suppresses hematopoiesis by releasing exosomes that contain microRNAs targeting c-MYB. Sci. Signal 2016, 9, ra88. [CrossRef]

79. Yeh, Y.Y.; Ozer, H.G.; Lehman, A.M.; Maddocks, K.; Yu, L.; Johnson, A.J.; Byrd, J.C. Characterization of CLL exosomes reveals a distinct microRNA signature and enhanced secretion by activation of BCR signaling. Blood 2015, 125, 3297-3305. [CrossRef] [PubMed]

80. Maruyama, T.; Kono, K.; Mizukami, Y.; Kawaguchi, Y.; Mimura, K.; Watanabe, M.; Izawa, S.; Fujii, H. Distribution of Th17 cells and FoxP3(+) regulatory $\mathrm{T}$ cells in tumor-infiltrating lymphocytes, tumor-draining lymph nodes and peripheral blood lymphocytes in patients with gastric cancer. Cancer Sci. 2010, 101, 1947-1954. [CrossRef] [PubMed]

81. Grazioli, P.; Orlando, A.; Giordano, N.; Noce, C.; Peruzzi, G.; Scafetta, G.; Screpanti, I.; Campese, A.F. NF-kappaB1 Regulates Immune Environment and Outcome of Notch-Dependent T-Cell Acute Lymphoblastic Leukemia. Front. Immunol. 2020, 11, 541. [CrossRef] [PubMed]

82. Manlove, L.S.; Berquam-Vrieze, K.E.; Pauken, K.E.; Williams, R.T.; Jenkins, M.K.; Farrar, M.A. Adaptive Immunity to Leukemia Is Inhibited by Cross-Reactive Induced Regulatory T Cells. J. Immunol. 2015, 195, 4028-4037. [CrossRef]

83. Niedzwiecki, M.; Budzilo, O.; Adamkiewicz-Drozynska, E.; Pawlik-Gwozdecka, D.; Zielinski, M.; Maciejka-Kemblowska, L.; Szczepanski, T.; Trzonkowski, P. CD4(+)CD25(high)CD127(low/-)FoxP3 (+) Regulatory T-Cell Population in Acute Leukemias: A Review of the Literature. J. Immunol. Res. 2019, 2019, 2816498. [CrossRef]

84. Hossain, F.; Majumder, S.; Ucar, D.A.; Rodriguez, P.C.; Golde, T.E.; Minter, L.M.; Osborne, B.A.; Miele, L. Notch Signaling in Myeloid Cells as a Regulator of Tumor Immune Responses. Front. Immunol. 2018, 9, 1288. [CrossRef] [PubMed]

85. Lopez-Lopez, S.; Monsalve, E.M.; de Avila, R.M.J.; Gonzalez-Gomez, J.; de Leon, H.N.; Ruiz-Marcos, F.; Baladron, V.; Nueda, M.L.; Garcia-Leon, M.J.; Screpanti, I.; et al. NOTCH3 signaling is essential for NF-kappaB activation in TLR-activated macrophages. Sci. Rep. 2020, 10, 14839. [CrossRef] [PubMed]

86. Du, T.; Zamore, P.D. MicroPrimer: The biogenesis and function of microRNA. Development 2005, 132, 4645-4652. [CrossRef]

87. Han, J.; Lee, Y.; Yeom, K.H.; Kim, Y.K.; Jin, H.; Kim, V.N. The Drosha-DGCR8 complex in primary microRNA processing. Genes Dev. 2004, 18, 3016-3027. [CrossRef] [PubMed]

88. Yi, R.; Qin, Y.; Macara, I.G.; Cullen, B.R. Exportin-5 mediates the nuclear export of pre-microRNAs and short hairpin RNAs. Genes Dev. 2003, 17, 3011-3016. [CrossRef]

89. O'Brien, J.; Hayder, H.; Zayed, Y.; Peng, C. Overview of MicroRNA Biogenesis, Mechanisms of Actions, and Circulation. Front. Endocrinol. 2018, 9, 402. [CrossRef]

90. Segal, M.; Slack, F.J. Challenges identifying efficacious miRNA therapeutics for cancer. Expert Opin. Drug Discov. 2020, 15, 987-992. [CrossRef] [PubMed]

91. Freud, A.G.; Caligiuri, M.A. Human natural killer cell development. Immunol. Rev. 2006, 214, 56-72. [CrossRef] [PubMed]

92. Freud, A.G.; Keller, K.A.; Scoville, S.D.; Mundy-Bosse, B.L.; Cheng, S.; Youssef, Y.; Hughes, T.; Zhang, X.; Mo, X.; Porcu, P.; et al. NKp80 Defines a Critical Step during Human Natural Killer Cell Development. Cell Rep. 2016, 16, 379-391. [CrossRef] 
93. Freud, A.G.; Mundy-Bosse, B.L.; Yu, J.; Caligiuri, M.A. The Broad Spectrum of Human Natural Killer Cell Diversity. Immunity 2017, 47, 820-833. [CrossRef] [PubMed]

94. Caligiuri, M.A. Human natural killer cells. Blood 2008, 112, 461-469. [CrossRef] [PubMed]

95. Calin, G.A.; Cimmino, A.; Fabbri, M.; Ferracin, M.; Wojcik, S.E.; Shimizu, M.; Taccioli, C.; Zanesi, N.; Garzon, R.; Aqeilan, R.I.; et al. MiR-15a and miR-16-1 cluster functions in human leukemia. Proc. Natl. Acad. Sci. USA 2008, 105, 5166-5171. [CrossRef]

96. Sullivan, R.P.; Leong, J.W.; Schneider, S.E.; Ireland, A.R.; Berrien-Elliott, M.M.; Singh, A.; Schappe, T.; Jewell, B.A.; Sexl, V.; Fehniger, T.A. MicroRNA-15/16 Antagonizes Myb To Control NK Cell Maturation. J. Immunol. 2015, 195, 2806-2817. [CrossRef]

97. Bezman, N.A.; Chakraborty, T.; Bender, T.; Lanier, L.L. miR-150 regulates the development of NK and iNKT cells. J. Exp. Med. 2011, 208, 2717-2731. [CrossRef]

98. Haraguchi, K.; Suzuki, T.; Koyama, N.; Kumano, K.; Nakahara, F.; Matsumoto, A.; Yokoyama, Y.; Sakata-Yanagimoto, M.; Masuda, S.; Takahashi, T.; et al. Notch activation induces the generation of functional NK cells from human cord blood CD34-positive cells devoid of IL-15. J. Immunol. 2009, 182, 6168-6178. [CrossRef]

99. Yang, C.; Shen, C.; Feng, T.; Li, H. Noncoding RNA in NK cells. J. Leukoc. Biol. 2019, 105, 63-71. [CrossRef]

100. Starczynowski, D.T.; Morin, R.; McPherson, A.; Lam, J.; Chari, R.; Wegrzyn, J.; Kuchenbauer, F.; Hirst, M.; Tohyama, K.; Humphries, R.K.; et al. Genome-wide identification of human microRNAs located in leukemia-associated genomic alterations. Blood 2011, 117, 595-607. [CrossRef]

101. Romanski, A.; Bug, G.; Becker, S.; Kampfmann, M.; Seifried, E.; Hoelzer, D.; Ottmann, O.G.; Tonn, T. Mechanisms of resistance to natural killer cell-mediated cytotoxicity in acute lymphoblastic leukemia. Exp. Hematol. 2005, 33, 344-352. [CrossRef] [PubMed]

102. Leong, J.W.; Sullivan, R.P.; Fehniger, T.A. microRNA management of NK-cell developmental and functional programs. Eur. J. Immunol. 2014, 44, 2862-2868. [CrossRef]

103. Garzon, R.; Heaphy, C.E.; Havelange, V.; Fabbri, M.; Volinia, S.; Tsao, T.; Zanesi, N.; Kornblau, S.M.; Marcucci, G.; Calin, G.A.; et al. MicroRNA 29b functions in acute myeloid leukemia. Blood 2009, 114, 5331-5341. [CrossRef] [PubMed]

104. Gao, S.M.; Xing, C.Y.; Chen, C.Q.; Lin, S.S.; Dong, P.H.; Yu, F.J. miR-15a and miR-16-1 inhibit the proliferation of leukemic cells by down-regulating WT1 protein level. J. Exp. Clin. Cancer Res. 2011, 30, 110. [CrossRef]

105. Rouce, R.H.; Shaim, H.; Sekine, T.; Weber, G.; Ballard, B.; Ku, S.; Barese, C.; Murali, V.; Wu, M.F.; Liu, H.; et al. The TGFbeta/SMAD pathway is an important mechanism for NK cell immune evasion in childhood B-acute lymphoblastic leukemia. Leukemia 2016, 30, 800-811. [CrossRef] [PubMed]

106. Cho, S.; Dong, J.; Lu, L.F. Cell-intrinsic and -extrinsic roles of miRNAs in regulating T cell immunity. Immunol. Rev. 2021, 304, 126-140. [CrossRef]

107. Tapeh, B.E.G.; Mosayyebi, B.; Samei, M.; Basmenj, B.H.; Mohammadi, A.; Alivand, M.R.; Hassanpour, P.; Solali, S. microRNAs involved in T-cell development, selection, activation, and hemostasis. J. Cell Physiol. 2020, 235, 8461-8471. [CrossRef]

108. Hu, L.; Mao, L.; Liu, S.; Zhao, J.; Chen, C.; Guo, M.; He, Z.; Yang, J.; Xu, W.; Xu, L. Functional Role of MicroRNAs in Thymocyte Development. Int. Arch. Allergy Immunol. 2019, 178, 315-322. [CrossRef]

109. Zhou, B.; Wang, S.; Mayr, C.; Bartel, D.P.; Lodish, H.F. MiR-150, a microRNA expressed in mature B and T cells, blocks early B cell development when expressed prematurely. Proc. Natl. Acad. Sci. USA 2007, 104, 7080-7085. [CrossRef]

110. Ferrandino, F.; Bernardini, G.; Tsaouli, G.; Grazioli, P.; Campese, A.F.; Noce, C.; Ciuffetta, A.; Vacca, A.; Besharat, Z.M.; Bellavia, D.; et al. Intrathymic Notch3 and CXCR4 combinatorial interplay facilitates T-cell leukemia propagation. Oncogene 2018, 37, 6285-6298. [CrossRef]

111. Moloudizargari, M.; Hekmatirad, S.; Mofarahe, Z.S.; Asghari, M.H. Exosomal microRNA panels as biomarkers for hematological malignancies. Curr. Probl. Cancer 2021, 45, 100726. [CrossRef] [PubMed]

112. Mansour, M.R.; Sanda, T.; Lawton, L.N.; Li, X.; Kreslavsky, T.; Novina, C.D.; Brand, M.; Gutierrez, A.; Kelliher, M.A.; Jamieson, C.H.; et al. The TAL1 complex targets the FBXW7 tumor suppressor by activating miR-223 in human T cell acute lymphoblastic leukemia. J. Exp. Med. 2013, 210, 1545-1557. [CrossRef] [PubMed]

113. Fragoso, R.; Mao, T.; Wang, S.; Schaffert, S.; Gong, X.; Yue, S.; Luong, R.; Min, H.; Yashiro-Ohtani, Y.; Davis, M.; et al. Modulating the strength and threshold of NOTCH oncogenic signals by mir-181a-1/b-1. PLoS Genet. 2012, 8, e1002855. [CrossRef]

114. Drobna, M.; Szarzynska-Zawadzka, B.; Dawidowska, M. T-cell acute lymphoblastic leukemia from miRNA perspective: Basic concepts, experimental approaches, and potential biomarkers. Blood Rev. 2018, 32, 457-472. [CrossRef]

115. Lorsbach, R.B.; Moore, J.; Mathew, S.; Raimondi, S.C.; Mukatira, S.T.; Downing, J.R. TET1, a member of a novel protein family, is fused to MLL in acute myeloid leukemia containing the $t(10 ; 11)(q 22 ; q 23)$. Leukemia 2003, 17, 637-641. [CrossRef] [PubMed]

116. Gebarowska, K.; Mroczek, A.; Kowalczyk, J.R.; Lejman, M. MicroRNA as a Prognostic and Diagnostic Marker in T-Cell Acute Lymphoblastic Leukemia. Int. J. Mol. Sci. 2021, 22, 5317. [CrossRef] [PubMed]

117. Fuziwara, C.S.; Kimura, E.T. Insights into Regulation of the miR-17-92 Cluster of miRNAs in Cancer. Front. Med. $2015,2,64$. [CrossRef] [PubMed]

118. Ling, Z.; Fang, Z.G.; Wu, J.Y.; Liu, J.J. The depletion of Circ-PRKDC enhances autophagy and apoptosis in T-cell acute lymphoblastic leukemia via microRNA-653-5p/Reelin mediation of the PI3K/AKT/mTOR signaling pathway. Kaohsiung J. Med. Sci. 2021, 37, 392-401. [CrossRef] [PubMed]

119. Correia, N.C.; Melao, A.; Povoa, V.; Sarmento, L.; de Cedron, G.M.; Malumbres, M.; Enguita, F.J.; Barata, J.T. MicroRNAs regulate TAL1 expression in T-cell acute lymphoblastic leukemia. Oncotarget 2016, 7, 8268-8281. [CrossRef] 
120. Hori, S.; Nomura, T.; Sakaguchi, S. Control of regulatory T cell development by the transcription factor Foxp3. Science 2003, 299, 1057-1061. [CrossRef]

121. Cobb, B.S.; Hertweck, A.; Smith, J.; O'Connor, E.; Graf, D.; Cook, T.; Smale, S.T.; Sakaguchi, S.; Livesey, F.J.; Fisher, A.G.; et al. A role for Dicer in immune regulation. J. Exp. Med. 2006, 203, 2519-2527. [CrossRef]

122. Haas, J.D.; Nistala, K.; Petermann, F.; Saran, N.; Chennupati, V.; Schmitz, S.; Korn, T.; Wedderburn, L.R.; Forster, R.; Krueger, A.; et al. Expression of miRNAs miR-133b and miR-206 in the Il17a/f locus is co-regulated with IL-17 production in alphabeta and gammadelta T cells. PLoS ONE 2011, 6, e20171. [CrossRef] [PubMed]

123. Grazioli, P.; Felli, M.P.; Screpanti, I.; Campese, A.F. The mazy case of Notch and immunoregulatory cells. J. Leukoc. Biol. 2017, 102, 361-368. [CrossRef]

124. Lv, M.; Wang, K.; Huang, X.J. Myeloid-derived suppressor cells in hematological malignancies: Friends or foes. J. Hematol. Oncol. 2019, 12, 105. [CrossRef] [PubMed]

125. Baghbani, E.; Noorolyai, S.; Duijf, P.H.G.; Silvestris, N.; Kolahian, S.; Hashemzadeh, S.; Kojabad, B.A.; FallahVazirabad, A.; Baradaran, B. The impact of microRNAs on myeloid-derived suppressor cells in cancer. Hum. Immunol. 2021, 82, 668-678. [CrossRef]

126. Hassan, N.M.; Refaat, L.A.; Ismail, G.N.; Abdellateif, M.; Fadel, S.A.; AbdelAziz, R.S. Diagnostic, prognostic and predictive values of miR-100 and miR-210 in pediatric acute lymphoblastic Leukemia. Hematology 2020, 25, 405-413. [CrossRef]

127. Nair, R.A.; Verma, V.K.; Beevi, S.S.; Rawoof, A.; Alexander, L.E.; Prasad, E.R.; Kumari, P.K.; Kumar, P.; Kumar, D.L. MicroRNA Signatures in Blood or Bone Marrow Distinguish Subtypes of Pediatric Acute Lymphoblastic Leukemia. Transl. Oncol. 2020, 13, 100800. [CrossRef]

128. Lv, M.; Zhu, S.; Peng, H.; Cheng, Z.; Zhang, G.; Wang, Z. B-cell acute lymphoblastic leukemia-related microRNAs: Uncovering their diverse and special roles. Am. J. Cancer Res. 2021, 11, 1104-1120. 